\title{
BÁLINT CSANÁD: THE AVARS, BYZANTIUM AND ITALY \\ A Study in Chorology and Cultural History
}

\section{SAMU LeVENTE}

Magyar Régészet 8. évf. (2019), 3. szám, pp. 44-49, https://doi.org/10.36245/mr.2019.3.6

Az avar kor kutatásában Hampel József 1905-ben megjelent nagy munkájától (Hampel, 1905) számitva több, mint 100 év után, a 2010-es évek végén egy olyan kötet megjelenésének örülhetünk, amely széleskörü nemzetközi kontextusban tárgyalja az avar kori Kárpát-medence leletanyagát. A szerzö teljességre törekszik: a jelen kutatási helyzet ${ }^{1}$ mellett elérhetö legtöbb avar kori tárgytipus, temetkezési szokás, jelenség figyelembe vételével hozott létre egy olyan szintézist, amely átfogó képet nyújt az avar kor kapcsolati rendszeréröl, különös tekintettel a mediterrán kapcsolatokra, illetve azok differenciálására.

A könyv megjelenésére régóta számíthattunk, különösen, ha végigtekintünk a szerző pályájának elmúlt 30-40 évén. Nem hagyhatjuk ugyanis figyelmen kívül, hogy éppen 30 évvel ezelőtt publikálta a bemutatandó kötet szerzője korszakos müvét a kelet-európai sztyepp régészetéről, amelyben elsőként és azóta utolsóként összegezte Kelet-Európa kora középkorának régészeti eredményeit, feltárva a Kárpát-medence kelet-európai kapcsolatainak számos részletét (BÁLINT, 1989). Figyelme azonban már a '80-as évek közepétől fokozatosan a Mediterráneum, ezen belül a bizánci régészet felé irányult (BÁLINT, 1985, pp. 209-223). Ennek egyik első komolyabb megnyilvánulása volt 1992-ben megjelent könyve az Üč Tepe-i sírról (BÁLINT, 1992, pp. 309-496), ${ }^{2}$ s ide sorolhatjuk meghatározó tanulmányát az avarok Kárpát-medencébe érkezéséről (BÁlint, 1993, pp. 195-273). A következő évek kutatásai 2004-ben formálódtak ismét könyvvé: a nagyszentmiklósi kincs feldolgozása és kiértékelése

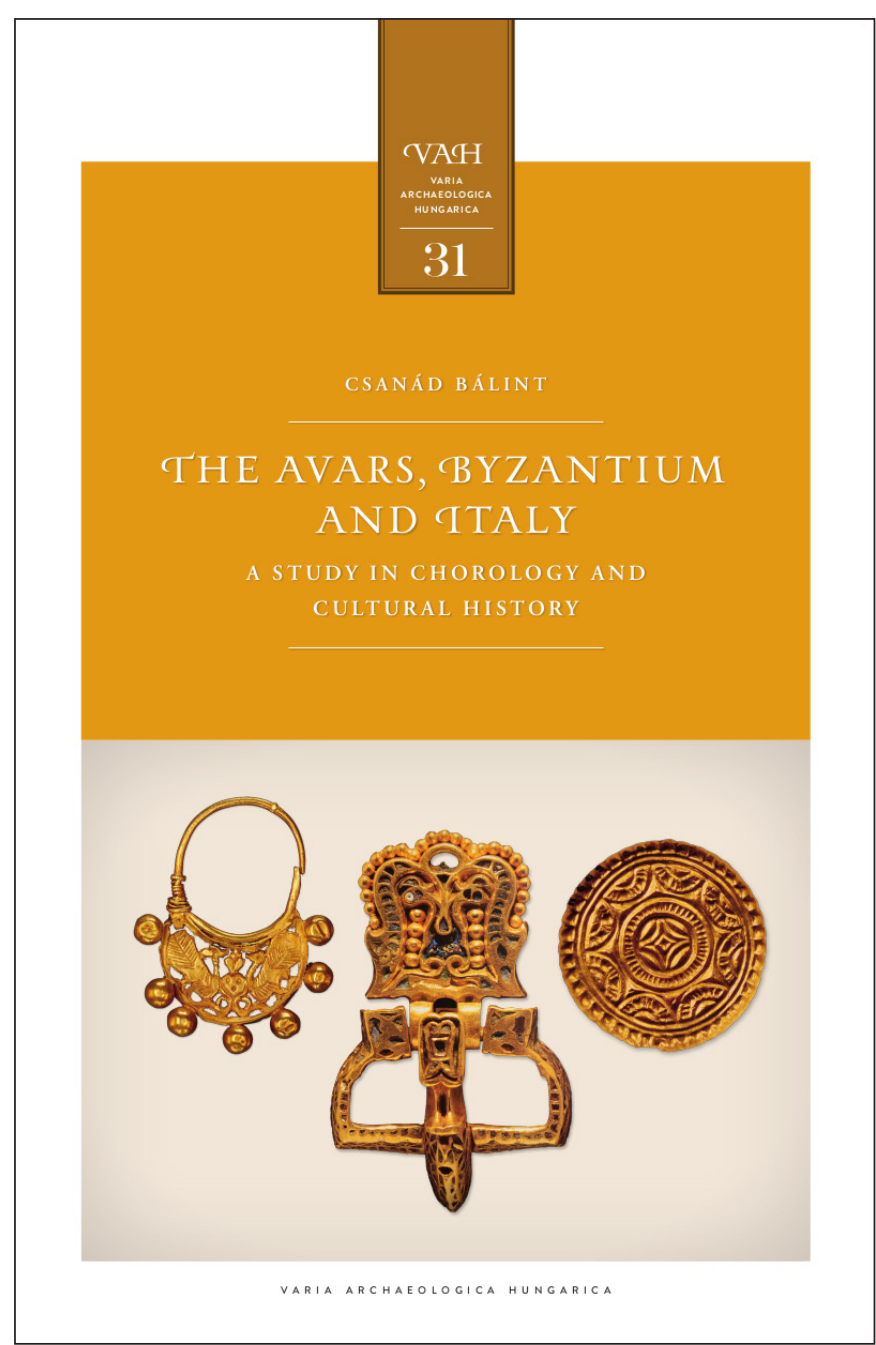

Bálint Csanád: The Avars, Byzantium and Italy. A study in chorology and cultural history Varia Archaeologica Hungarica 31, Budapest: Archaeolingua, 2019

Keménytábla, 372 oldal, 82 ábra ISBN 978-615-5766-23-7 magyar nyelven jelent meg, majd ugyanez az anyag átdolgozott formában 2010-ben, németül is napvilágot látott (BÁLINT, 2004; 2010). Az azóta eltelt évek munkájának eredménye a jelen kötet, immár egy teljes pályafutás olvasmányaival és minden tapasztalatával kiegészítve.

A szóban forgó mü természetesen nem áll előzmények nélkül, több kötet és tanulmány jelezte az elmúlt évek során, hogy az avar kor kutatása szintet lépett az elmúlt 20-30 évben. A kutatástörténet részletes tár-

\footnotetext{
A kézirat lezárásának éve 2016, azóta csak a lényegesebb szakirodalmak integrálása történt meg.

2 Később magyar nyelven, kora avar kori hangsúllyal: Bálint, 1994.
} 
gyalása nélkül is meg kell említenünk Garam Éva 2001-ben megjelent könyvét az avar kori bizánci, vagy bizánci jellegű tárgyakról (GARAM, 2001), valamint Vida Tivadar már megjelent (VIDA, 2000, pp. 367-377; 2016; 2017) és megjelenés alatt álló munkái is meghatározóak az avar kori kulturális kapcsolatok feltérképezésében és mélyebb megértésében (VIDA, 2018). Szerencsés egybeesés, hogy a történettudomány oldaláról is két jelentős, 2018-ban megjelent monográfia tárgyalja az avar kort: az egyik Georgios Kardaras tollából (KARDARAS, 2018), a másik pedig Walter Pohltól származik (PoHL, 2018; ez utóbbi az 1988-ban megjelent könyvének frissített, angol nyelvü változata). Kijelenthetjük, hogy az elmúlt években sorra megjelent prominens publikációk - közöttük a nagy sírszámú temetök közlései - katalizálták a magyar kutatást is. ${ }^{3}$

Azonban jelen kötet nem csak a magyarországi avar kutatástörténetet gazdagítja, hanem a nemzetközi, kora középkori távolsági kapcsolatokat kutató szakirodalmat is. Hasonló munkák születtek már Itália (Keim, 2007), Szicília (MetaXas, 2009), Dél-Németország (DrauschKe, 2011) vonatkozásában, s egyre kiterjedtebb az egyes kistárgy-típusokat feldolgozó szakirodalom is (P1. SchULze-DöRRLAmm 2002; 2009; BÖHLENDORF-ARSLAN\& RiCCI 2012), ahogy a bizánci régészeti anyag feldolgozása is egyre fejlödik (BoLlóK, 2015, pp. 265-314). Jelen kötet súlypontiságát az adja, hogy ebbe a kiterjedt, nemzetközi hálózatba helyezi el az avar kor kutatását, pozicionálja az avar kori Kárpát-medencét, egyúttal pedig mélyreható betekintést nyújt az avar kori régészet alapvető problémáiba. Aki azonban ezen a könyvön keresztül szeretne megismerkedni az avar régészettel, ne számítson könnyü olvasmányra: a szerző következetesen végigviszi az általa felvetett lényegi kérdéseket a választott módszer szerint. A teljesség igénye nélkül olyan kérdések merülnek fel a könyv olvasása során, mint az első generáció problémája, a 8. századi anyagi kultúra egységesülése, a technológiai váltások és azok elterjedések kérdése, a Kárpát-medencén belüli avar kori régiók és az „üres” (gyéren lakott?) területek problémája, a Keszthelyen és környékén elöforduló lelöhelyek interpretációja, a társadalmi státusz és rétegződés, a kereskedelem és a mühelyek kérdésköre, a mobilitás - beleértve a tárgyak mozgását -, a Kárpát-medence geopolitikai helyzete az avar korban és az ezzel összefüggő külső kapcsolatok, valamint az avarok jellegzetes kulturális sajátosságai.

A kötet tíz fejezetből áll, illetve tartalmaz egy függeléket a szövegben előforduló tárgyak listáival, valamint szakirodalmi hivatkozásaikkal. A szerző elsődleges célja, hogy a bizánci és itáliai kapcsolatokat új nézőpontból világítsa meg (12. o.). Ehhez a korológia módszertanát választotta. A tíz fejezetből négy - a 3 ., 4., 7. és 8. - bizonyos tárgytípusok elterjedését vizsgálja, míg öt - a 2., 5., 6., 9. és 10. - elméleti kérdéseket vet fel és tárgyal, valamint a választott módszerrel elemzi a megfigyelt jelenségeket. A 2. és 9. fejezetek adják a kötet keretét: előbbiben a szerző röviden áttekinti az eddigi kutatásokat, különös tekintettel az itáliai kapcsolatok vizsgálatára, míg a 9. fejezetben a megfigyelt jelenségek és módszertani nehézségek kerülnek összefoglalásra. A tizedik fejezet tulajdonképpen egy esettanulmánynak tekinthető, amely az avar kori etnikai interpretáció problémáit világítja meg a kölkedi A és B temetők példáján keresztül (253-261. o.).

A harmadik fejezetben, amely egyben a kötet legterjedelmesebbje is ( 92 oldal), fekteti le a szerző a módszertani alapokat és a földrajzi kereteket: olyan tárgyak elterjedéseiben keresi a rendszerességet, amelyek feltételezett vagy bizonyított távolsági kapcsolatokkal rendelkeznek. Ennek során ugyanolyan hangsúlyt fektet bizonyos tárgytípusok sürüsödéseire, mint azok hiányára bizonyos területeken. Az elterjedések elsősorban az átfedések - alapján jelöl ki több régiót, melyeknek meghatározó szerepük lehetett a távolsági kapcsolatok fenntartásában, s amelyek markáns jegyeket mutatnak leletanyagukban és kulturális ismérveikben, például a temetkezési szokásokban (30-69. o.). A fejezet második felében a különböző elterjedések mögött rejlö lehetséges okok kerülnek sorra, ennek során a temetkezési szokások mellett esettanulmányként a bizánci érmek és az összecsukható székek előfordulásait és lehetséges kontextusba kerülését vizsgálja a kötet. A mühelyek lehetséges lokalizálása során elemzi a technológiai csoportokat - ezt a szempontot állítva a középpontba a formai hasonlóságok helyett -, valamint kitér a mühelyek kisugárzási körére és az árukhoz való hozzáférés lehetőségeire (84-89. o.). Bizonyos veret- és kerámiatípusok elterjedésének példáján keresztül elemzi a tárgyak lehetséges mozgását, az útvonalakat. A ruházat/viselet problémaköre

Rácz Zsófia az avar kori ötvössírokról (RÁcz, 2014), Somogyi Péter az éremleletekről (SomoGYI, 2014), Csiky Gergely a szúró- és vágófegyverekről (Csiky, 2015) írt jelentős összefoglaló munkát. 
után a különböző identitások potenciális visszatükröződését vizsgálja a régészeti anyagban (107-112. o.).

A negyedik fejezet tárgyalja a bizánci kapcsolatok vizsgálatának elméleti és gyakorlati problémáit. A főbb elméleti/módszertani kérdések között kitér az egykori birodalom földrajzi változásaira, a bizánci hatás alatt álló peremterületekre, az avar kori Kárpát-medence régészeti anyagának jellegére, szembeállítva azt a kelet-európai párhuzamos leletanyag összetételével (115-116. o.). Ezek után veszi sorra azokat a "bizánci" tárgyakat és viseleti elemeket, amelyeknek elterjedése Kelet-Európa területén megfigyelhetö (118-128. o.). Külön alfejezetet szentel az övgarnitúrák és övcsatok kérdéskörének, elemezve a tárgytípus elterjedésében megfigyelhető sürüsödéseket és a teljes hiányokat (129-155. o.). A fejezet egyik legfontosabb megállapítása, hogy az avar kori Kárpát-medence társadalma fontos fogyasztóként és közvetítőként (agent) müködött közre Kelet- és Délkelet-Európa ruházatának, viseletének alakításában, melynek számos bizánci eleme is volt (155. o.).

A kötet ötödik, talán legfontosabb fejezete tárgyalja az avar kori Kárpát-medence itáliai kapcsolatait, annak kutatástörténetét, a korszak Itáliájának politikai, geopolitikai és szomszédsági viszonyait (157-162. o.). A kapcsolatok lehetőségeinek modellezése során a Kiss Attila által megkezdett úton halad (KIss, 1996, pp. 300-302), de az elmúlt húsz év kutatási eredményeit is felhasználja és integrálja. A fejezet kiemelkedően fontos része az Itáliából származó Kárpát-medencei bizánci érmek számbavétele és kiértékelése (162164. o.), ezek után tér rá a valószínüsíthetően Itáliából származó tárgyak elemzésére. Konklúziója szerint az eredeztetés kérdését - hasonlóan Stephanie Keim munkájához Itália és Dél-Németország viszonylatában (KEIM, 2007) - egyelöre nem lehet minden tárgytípus esetében megnyugtatóan lezárni (165-173. o.), a kérdéskör eldöntése valószínűleg még természettudományos vizsgálatokkal kibővített résztanulmányok sorát igényli majd (BÜHLER, 2019, pp. 203-213).

A hatodik fejezet tárgyalja azt az elméleti kérdést, hogy miként érhették el az avar korban mediterrán eredetü tárgyak a Kárpát-medencét. A lehetséges módok számbavétele mellett a szerző megvizsgálja azt a kérdést is, hogy lehetett-e, s ha igen, milyen formában, kereskedelem az avarok körében. Ennek elemzéséhez felhasználta a régészetelméleti eredményeket, az írott forrásokat, valamint a régészeti adatokat utóbbiak vizsgálata során a közép-európai régiókat hasonlítja össze annak tükrében, hogy milyen jellegü és mennyiségü mediterrán tárgyak érték el öket, összevetésben az avar kori Kárpát-medencével (189-194. o.).

A hetedik fejezetben újra visszatérünk a Kárpát-medence belső területeire, ahol egy szükebben vett tárgycsoport, a "bizánci” és "bizánci jellegü” tárgyak elterjedését és előfordulásuk mennyiségét tárgyalja a szerző (196-213. o.). A kerámia-, fém- és üvegedények elemzése után részletesen vizsgálja az érmeket, az ékszereket, az övcsatokat, különválasztva a "bizánci” és “későantik bizánci” típusokat (VIDA, 2009 nyomán) (204-206. o.).

A nyolcadik fejezet a mediterrán kapcsolatok kulturális jelentőségét vizsgálja, a "dunántúli jelenség" kifejezést fejti ki részletesen, kvantitatív elemzéssel mutat rá a Dunántúl és az Alföld közötti különbségekre, majd ezekre keres magyarázatot. Az erdélyi tárgyak és elterjedések elemzésére kevesebb tér jut - ez elsősorban az ottani kutatási helyzetnek köszönhető. Az egykori Pannonia esetében olyan kérdéseket feszeget, mint a késő római mühelytradíciók lehetséges tovább élése (223-224. o.), valamint elemzi a Balkánról történő áttelepítések lehetőségét, illetve rámutat a régészeti azonosítás korlátaira (226-232. o.). Egy-egy alfejezetben tárgyalja a lehetséges nyugat- és kelet-európai hatásokat is (232-237. o.). Érvrendszere egyrészt földrajzi - miszerint Pannonia és a Duna-Tisza-köze, illetve az Alföld fekvése és szomszédságaik alapvetően befolyásolták a kapcsolataikat, másfelől kulturális - ezeket a kapcsolatokat magyaráznák a lehetségesen túlélő, s az avarok által itt talált népcsoportok, illetve azok meglévő hagyománya és kulturális kapcsolatai.

A kötet kilencedik fejezetében a szerző történeti modellt állít föl az avar kultúra és társadalom eltünésének magyarázatára. A 8. század végére kialakuló belső viszályok elsődleges okai a szerző szerint kulturálisak: bár érzékelhető egyfajta eltolódás a földművelés felé, az avar társadalom alapvető szocio-ökonómiai rendszere, hatalmi struktúrája változatlan marad, ez pedig szükségszerüen vezet a társadalom felbomlásához (243-251. o.). Ez a szál, a kultúra meghatározó mivolta, az egész könyvön végigvonul - a címtől egészen a záró fejezetig keresi a szerző különböző megnyilvánulásait. A kötet összesen több, mint 200 térkép 
Samu Levente • Bálint Csanád: The Avars, Byzantium And Italy. A Study in Chorology and Cultural History

segítségével, ca. 127 tárgytípus, jelenség és technológia bemutatásával komoly betekintést nyújt az avar kori Kárpát-medence mediterrán kapcsolatainak kérdéskörébe, különös tekintettel az itáliai kapcsolatokra, azokat átfogóan elemzi, így egy rendkívül részletes kép tárul a könyvet kezébe vevő olvasó elé a korszakról. Ahogy bevezetőjében a szerző is megemlíti, a kötet sokkal több kérdést tud felvetni, mint megoldani. Ezt is szem előtt tartva bízhatunk abban, hogy Bálint Csanád legújabb könyve újabb lendületet ad az avar kor hazai és nemzetközi kutatásának.

FeLHASZnÁlt IRODALOM

BÁlint, Cs. 1985

Zur Frage der byzantinischen Beziehungen im Fundmaterial Ungarns. Archäologische Forschungen zwischen 1970 und 1984. Mitteilungen des Archäologischen Instituts der Ungarischen Akademie der Wissenschaften 14, pp. 209-223.

BÁlint, Cs. 1989

Die Archäologie der Steppe. Steppenvölker zwischen Volga und Donau vom 6. bis zum 10. Jahrhundert. Wien - Köln: Böhlau.

BÁLint, Cs. 1992

Kontakte zwischen Iran, Byzanz und der Steppe. Das Grab von Üč Tepe (Sowj. Azerbajdžan) und der beschlagverzierte Gürtel im 6. und 7. Jahrhundert. In: F. Daim, ed. Awarenforschungen I. Archaeologia Austriaca, Beiheft. Wien: Institut für Ur- und Frühgeschichte, pp. 309-496.

BÁlint, Cs. 1993

Probleme der archäologischen Forschung zur awarischen Landnahme. Vorträge und Forschungen 41 (1), pp. 195-273.

BÁLINT, Cs. 1994

Kelet, a korai avarok és Bizánc kapcsolatai. Magyar Östörténeti Könyvtár 7. Szeged: Balassi.

BÁLInt, Cs. 2004

A nagyszentmiklósi kincs. Régészeti tanulmányok. Ser. Varia Archaeologica Hungarica 16a, Budapest: Balassi.

BÁLINT, Cs. 2010

Der Schatz von Nagyszentmiklós: archäologische Studien zur frühmittelalterlichen Metallgefäßkunst des Orients, Byzanz'und der Steppe. Ser. Varia Archaeologica Hungarica 16b. Budapest: Balassi.

BollóK, Á. 2015

The Archaeology of the Byzantine State - A Non-Specialist's Approach. Antaeus 33, pp. 265-314.

BöHlendorf-Arslan, B \& Ricci, A. 2012

Byzantine Small Finds in Archaeological Contexts. Byzas 15. Istanbul: Ege Yayinlari.

BÜHLER, B. 2019

Die awarisch-italischen Beziehungen aus goldschmiedtechnischer Sicht: Ein Vorbericht. Acta Archaeologica Academiae Scientiarum Hungaricae 70(1), 203-213. 
Samu Levente • Bálint Csanád: The Avars, Byzantium And Italy. A Study in Chorology and Cultural History

CsIKY, G. 2015

Avar-age Polearms and Edged Weapons: Classification, Typology, Chronology and Technology. East Central and Eastern Europe in the Middle Ages, 450-1450, 32. Leiden - Boston: Brill. doi: https://doi. org/10.1163/9789004304543

DrauschKe, J. 2011

Zwischen Handel und Geschenk - Studien zur Distribution von Objekten aus dem Orient, aus Byzanz und aus Mitteleuropa im östlichen Merowingerreich. Freiburger Beiträge zur Archäologie und Geschichte des ersten Jahrtausends 14. Rahden: Marie Leidorf.

GARAM, É. 2001

Funde byzantinischer Herkunft in der Awarenzeit vom Ende des 6. Bis zum Ende des 7. Jahrhunderts. Monumenta Avarorum Archaeologica 5. Budapest: Magyar Nemzeti Múzeum.

GARAM, É. 2018

Das awarenzeitliche Gräberfeld in Zamárdi-Rétiföldek. Teil III. Monumenta Avarorum Archaeologica 12. Budapest: Magyar Nemzeti Múzeum.

HAMPEL, J. 1905

Alterthümer des frühen Mittelalters in Ungarn I-III. Braunschweig.

KARDARAS, G. 2018

Byzantium and the Avars, 6th-9th Century AD: Political, Diplomatic and Cultural Relations. East Central and Eastern Europe in the Middle Ages, 450-1450, 51. Leiden - Boston: Brill. doi: https://doi. org/10.1163/9789004382268

KeIM, S. 2007

Kontakte zwischen dem alamannisch-bajuwarischen Raum und dem langobardenzeitlichen Italien. Archäologie Internationale 98. Rahden: Marie Leidorf.

KIss, A. 1996

Das awarenzeitlich gepidische Gräberfeld von Kölked-Feketekapu A. Monographien zur Frühgeschichte und Mittelalterarchäologie. Studien zur Archäologie der Awaren 2/5. Innsbruck: Wagner.

LÁSZLÓ, Gy. 2015

Das awarenzeitliche Gräberfeld in Csákberény-Orondpuszta. Monumenta Avarorum Archaeologica 11. Budapest: Magyar Nemzeti Múzeum 2015.

Metaxas, S. 2009

Die Materielle Kultur des byzantinischen Sizilien (6.-10. Jahrhundert). Unpublished Dissertation, Universität Wien.

MÜLLER, R. 2014

Die Gräberfelder von Keszthely-Fenékpuszta, Ödenkirche-Flur. Castellum pannonicum pelsonense 5. Rahden: Marie Leidorf.

PoHL, W. 2018

The Avars. A Steppe Empire in Central Europe, 567-822. Ithaca - London: Cornell University Press. doi: https://doi.org/10.7591/9781501729409 
Samu Levente • Bálint Csanád: The Avars, Byzantium And Italy. A Study in Chorology and Cultural History

RÁcz, Zs. 2014

Die Goldschmiedergräber der Awarenzeit. Monographien der Römisch-Germanischen Zentralmuseums 116. Mainz am Rhein: Verlag des Römisch-Germanischen Zentralmuseums.

Schulze-Dörrlamm, M. 2002

Byzantinische Gürtelschnallen und Gürtelbeschläge im Römisch-Germanischen Zentralmuseum. Teil I: Die Schnallen ohne Beschläg, mit Laschenbeschläg und mit festem Beschläg des 5. bis 7. Jahrhunderts. Kataloge RGZM 30, 1. Mainz am Rhein: Verlag des Römisch-Germanischen Zentralmuseums.

Schulze-Dörrlamm, M. 2009

Byzantinische Gürtelschnallen und Gürtelbeschläge im Römisch-Germanischen Zentralmuseum. Teil II. Die Schnallen mit Scharnierbeschläg und die Schnallen mit angegossenem Riemendurchzug des 7. bis 10. Jahrhunderts. Kataloge RGZM 30, 2. Mainz am Rhein: Verlag des Römisch-Germanischen Zentralmuseums.

Somogyi, P. 2014

Byzantinische Fundmünzen der Awarenzeit in ihrem europäischen Umfeld. Dissertationes pannonicae ex Instituto Archaeologico Universitatis de Rolando Eötvös Nominatae Budapestinensis provenientes IV/2. Budapest: ELTE.

VIDA, T. 2000

Die Ziergehänge der awarenzeitlichen Frauen im Karpatenbecken. Acta Archaeologica Academiae Scientiarum Hungaricae 51, pp. 367-377.

VIDA,T. 2009

Local and Foreign Romans? The Problem of the Late Antique Population of the 6th-7th Centuries AD in Pannonia. In: D. Quast, ed. Foreigners in Early medieval Europe: Thirtheen International Studies on Early Medieval Mobility. Mainz: Römisch-Germanisches Zentralmuseum 2009, pp. 233-260.

VIDA,T. 2016

Late Antique Metal Vessels in the Carpathian Basin. Hereditas Archaeologica Hungariae 1. Budapest: Archaeolingua.

VIDA,T. 2017

Die frühbyzantinische Messingkanne mit Jagdszenen von Budakalász (Ungarn). Budapest: Institut für Archäologie - Forschungszentrum für Humanwissenschaften - Ungarische Akademie der Wissenschaften.

VIDA,T. 2018

A sztyeppei, a bizánci és a Meroving Birodalmak között. Kulturális átalakulás a Kárpát-medencében a 6-7. században. Between the Steppean, Byzantine and Merovingian Empire. Cultural changes in the Carpathian Basin to 6th-7th century AD. Thesis for the title 'Doctor of the Academy.' Budapest: Hungarian Academy of Sciences. 